\title{
Structural adjustment and deforestation in Nicaragua*
}

\author{
SOLVEIG GLOMSRØD \\ Statistics Norway, P.O. Box 8131 Dep., N-0033 Oslo, NORWAY, \\ e-mail:sgl@ssb.no
}

\author{
MARIA DOLORES MONGE \\ Instituto Centroamericano de Administracion de Empresas (INCAE), \\ Managua, Nicaragua \\ HAAKON VENNEMO \\ ECON Centre for Economic Analysis, P.O. Box 6823 St. Olavs plass, \\ N-0130 Oslo, Norway. E-mail: haakon.vennemo@econ.no
}

\begin{abstract}
This paper investigates the impact of structural adjustment policies on deforestation taking place when the agricultural frontier advances into forest reserves in Nicaragua. A computable general equilibrium model incorporating deforestation by squatters is used for policy simulations. The opportunity cost of migrating to the frontier does not simply depend on wage income opportunity, but also on market prices of basic grain which determine the capacity to consume beyond subsistence food-level given a certain real wage. Reducing public expenditures both conserves forests and enhances economic growth, while showing positive distributional effects. On the other hand, a strong conservation trend following a sales tax increase is driven by increasing poverty in rural areas. Noticeably, there are policies which initially intensify deforestation, but turn out to ease the pressure on forests over time. Rapid economic growth does not ensure less pressure on forest reserves.
\end{abstract}

\section{Introduction}

Around 1990 Nicaragua entered a period of economic stabilization and adjustments after many years of social and economic turbulence. ${ }^{1}$ Markets have been deregulated, the domestic currency deflated, public expenditures reduced and the tax system reformed. The implemented measures are crucial to long-term development. The transition period, however, has been characterized by large scale unemployment and increased poverty for a substantial part of the population. Negative long-term effects may

* This study is carried out with financial support from The Research Council of Norway. We are indebted to Knut H. Alfsen for valuable research assistance, and to Ådne Cappelen, Torstein Bye and two anonymous reviewers for valuable comments.

${ }^{1}$ See Gibson (1993) for an economic analysis of this period. 
occur due to increased poverty and deterioration of public education and health services. Also, long-term effects on future production capacity and future income generation may be related to deterioration of the natural resource base, for instance if poverty intensifies the pressure on agricultural land and forest reserves.

The focus of this paper is on the impact of structural adjustment policy on deforestation in Nicaragua. Several factors have initiated a migration wave towards the forests for subsistence farming. After several years of war, the forests are again accessible to people. The economic crisis and rising unemployment have set fire to deforestation, literally speaking. A population growth of 3.2 per cent provides overall pressure on natural resources.

Currently, the forests in Nicaragua are cleared at a rate of about $150,000-200,000$ ha per year. Fuelwood extraction and commercial logging are factors behind this trend, but the dominant driving force is the advance of the agricultural frontier (Monge, 1995). Migrators move from the western dry region towards the east where humid tropical forests remain. Their main activity is basic grain production, based on slash and burn practices. Abandoned plots are to some extent converted to low productive pasture (or left idle due to their marginal quality), but ranching is generally not reported to contribute significantly to the current rate of deforestation.

In our approach we highlight the inter-relation between poverty, employment opportunities and deforestation caused by migration to the agricultural frontier in Nicaragua. We question how particular policy elements like tax reform, reduced public expenditure and improved external balance affect the pressure on the still significant humid tropical forests of Nicaragua. For this purpose we employ a computable general equilibrium (CGE) model containing an informal food producing frontier sector, advancing into forest land. Forest soil provides land for subsistence farming over a few years, but thereafter deteriorates rapidly, causing deforestation to go on even with a constant population of squatters. In the model, general economic policies affect the flow of new settlers to forest reserves by providing more or less attractive alternative wage income opportunities within the market economy.

In the literature so far the deforestation problem has mainly been dealt with in a partial manner and the actual linkages between general economic policies and the pressure on forests remain diffuse. In a recent theoretical approach, Deacon (1995) discusses the impact of tax policies on deforestation and social welfare within a general equilibrium framework. Deacon treats land as a homogenous input in a single agricultural sector. So do Thiele and Wiebelt (1993) in an empirical model for Cameroon. Thus, it is the general development in supply and demand of an aggregate agricultural good which is driving the demand for input of land in those models. This conceals some important aspects in rural production technology and income generation which might affect the land use and rate of deforestation.

First, the production technology at the agricultural frontier is far more labour and land intensive than the average stationary cultivation practices. 
Technology is determined by the lack of infrastructure, making commercial inputs like fertilizer and pesticides too expensive and production for markets practically beyond reach. This means that various general economic policies might affect the more intensively producing permanent agriculture without penetrating to the agricultural frontier. Second, at the frontier, crops are grown for subsistence. When dealing with the deforestation problem, this has important consequences. The link between deforestation and economic policy in developing countries may primarily be found in the labour market and the off-frontier potential for income generation, and not so much in the changes in the market for agricultural crops in general. Various policies might affect stationary and frontier farming differently and thus generate different deforestation rates, although they have similar impacts on total production in agriculture. Our approach seeks to bring more realism into the policy analysis of deforestation in this respect.

Other empirical and economy-wide approaches to deforestation frequently deal with the deforestation pressure generated by commercial logging. Thiele and Wiebelt (1993) integrate a forward looking forestry sector in their CGE framework for Cameroon. Persson and Munasinghe (1995) go one step further and include deforestation by squatters for either logging or subsistence farming in Costa Rica. An interesting result of the latter study is that stumpage price increases will reduce deforestation for logging, but total deforestation will nevertheless increase, because general equilibrium effects shift resources towards agriculture. The fact that indirect allocation effects may differ in direction and even dominate over the direct effect identified in partial equilibrium analysis clearly demonstrates the importance of using an economy-wide approach. To capture these indirect effects of economic reforms on the deforestation rate in Nicaragua, we apply a CGE model. By including land clearing for subsistence farming in forest reserves in the model, we look for determinants of migration to forest reserves through income and consumer options facing the labour force.

In section 2 we briefly describe the CGE core model and in more detail present the modelling of technology and income generation at the agricultural frontier. Section 3 outlines the 'business as usual' scenario and describes the policy reforms which we will focus on. Section 4 presents results from model runs while section 5 concludes.

\section{The model}

\subsection{CGE core model}

The core model was developed at the Business School of Central America (INCAE) in Managua and further developed for environmental analysis in cooperation with Statistics Norway (see De Franco et al., 1993 or Alfsen et al., 1996 for a study which incorporates soil degradation impacts on economic growth). For this study of deforestation by squatters, the model has been specially developed to include the production and deforestation at the agricultural frontier and further describe incentives for labour migration. 
The model is a fairly standard (static) computable equilibrium model in line with models presented by Dervis et al. (1982). Producers and consumers behave as maximizers of profits and utility respectively. Markets for goods clear, but labour faces the possibility of unemployment, which runs high in Nicaragua. The model contains no capital market. Although a private capital market has emerged after the deregulation, credit facilities are still inadequate and profitability and capacity to pay rent do not yet correspond to the actual investment criteria. The model is calibrated to 1991 data. The equations and some central parameter values are listed in the appendix.

\section{Producers}

There are 27 sectors each producing a single commodity. Among these are 12 agricultural sectors, classified as rural, all others are urban sectors. Commodities are produced by labour, capital, and intermediates. The intermediates are used in fixed proportions to the production levels. Demand for labour is determined by equating the value of the marginal product of labour to the wage rate, and is decreasing in the real wage rate. Each sector receives a fixed share of total nominal investments. Production functions are Cobb-Douglas, except in the agricultural frontier sector where the only input factor, labour, is proportional to output, which is a linear composite of basic grains.

\section{Labour market}

Total labour supply is growing by a constant rate based on population growth forecasts. The model incorporates a rural-urban migration mechanism in the tradition of Harris and Todaro (1970), where there is unemployment in the urban sector, but migration to cities is positive as long as expected urban income, adjusted for the probability of getting a job, is higher than the rural wage. The model is run in two different versions, with constant and flexible real urban wage, respectively, to illustrate the two extremes among wage formation rules and unemployment regimes.

\section{Social classes and distribution}

The income distribution is the driving force behind migration of labour. To state this force explicitly, the model traces the income of five social classes: Campesinos, frontier farmers, workers, petty capitalists, and capitalists. Income consists of profit, wages, and transfers from abroad. Campesinos earn rent as agricultural smallholders, while big agricultural producers are counted as capitalists. Workers earn their wages, in either urban or rural sectors, and frontier farmers earn the imputed income from their production of basic grain. Capitalists receive a share of rural profit and urban profit, while petty capitalists (informal producers) receive a share of profits in urban sectors. Each of the five classes has a consumption pattern formalized as a linear expenditure system. For capitalists, the minimum consumption is 10 per cent, for workers and petty capitalists 15 per cent, and 20 per cent for campesinos. At the agricultural frontier, the total production is used for own consumption. 
Saving and investment

Private savings equals total income less taxes and total private expenditure. There are highly different saving rates among classes, hence the income distribution strongly influences the level of total saving. The public sector benefits from foreign transfers, through official development assistance, while workers, capitalists, and petty capitalists benefit from private remittances. Public saving is a residual of public revenues less exogenous public expenditure.

Investments in real capital are determined by total savings. Foreign savings are assumed to be exogenous; so domestic savings are the essential variables for determining the economic growth potential. A dominant share of domestic savings stems from profit, while workers and campesinos contribute insignificantly.

The capital stock in period $t+1$ is equal to the capital stock in period $t$ less depreciation plus investment in period $t$. Allocation of investment by destination is determined by fixed (base year) coefficients. The sectoral pattern of investment by destination is translated into demand for investment goods by sector of origin.

\section{Foreign trade}

Domestically produced goods compete with foreign goods both on the world market and at home. It is assumed that domestically produced commodities and imported goods of the same category are non-perfect substitutes (the Armington assumption). The higher the price of the domestically produced commodity relative to the price of the imported variety, the higher is the import share. On the production side, a CET function indicates that domestic output cannot be shifted costlessly between the domestic market and the world market. The higher the price on exports relative to the domestic price, the higher the export share. The elasticities of trade are 1.4 for exports and 1.2 for imports. Both are guesstimates. The relatively limited flexibility assigned to the marketing of domestic output may indicate some hardship in entering foreign markets after a period with disincentives for export (i.e., overvalued currency and regulations). Further, coffee, which is a main export good, is a perennial crop. To respond to price changes with increased supply of export quality beans is likely to be time consuming.

World market prices are exogenous, i.e. it is assumed that Nicaragua is a small country unable to affect external terms of trade. The nominal exchange rate is set by the government. The prices of imported and exported goods are determined as the world market prices multiplied by the exchange rate and adjusted for tariffs.

Below we discuss in more detail the production system at the agricultural frontier and how we model the links between the frontier and the rest of the economy.

\subsection{Production technology at the agricultural frontier}

The agricultural land extends in many directions, and the frontier is no clearly defined area. However, in Nicaragua today, there are two distinct areas which are colonial centres, combining the features of rapid expan- 
sion of cultivation with the availability of virgin forest. These areas are Bosawas in the north and Indio-Maiz in the south, both forest reserves. The migrators are settling with a cultivation pattern and a technology which is described below, based on surveys of the frontier activity carried out by the Ministry of the Environment (GTZ/MARENA, 1992) and CIPRES (1992). The production system is more thoroughly described by Monge (1995).

Table 1 presents the labour and land characteristics of a typical squatter family. The representative family of eight persons disposes on average four man-years of labour, which means that big children and women take part in production (although children below 12 years are assumed not to contribute). The family clears about 12 manzanas ( $1 \mathrm{mz}=0.7 \mathrm{ha})$ to keep aggressive vegetation and shadow on suitable distance from an actually cultivated plot size of $8 \mathrm{mz}$. The climate allows for three seasons per year (24 mz-seasons).

Table 2 depicts the typical allocation of labour on the three cultivated crops, taken from CIPRES (1992). The crop pattern allocates $12 \mathrm{mz}$-seasons to maize, $8 \mathrm{mz}$-seasons to beans and $4 \mathrm{mz}$-seasons to rice. Representative yields of maize, beans, and rice are 20, 10, and 35 quintales (QQ) respectively. The family labour produces 33.6 QQ of maize, 11.2 QQ of beans and 19.6 QQ of rice on average per man-year, when a 30 per cent harvest loss is taken into account.

Table 3 lists the market prices of basic grain used to impute an income

Table 1. Representative family farm at the frontier

\begin{tabular}{llllll}
\hline $\begin{array}{l}\text { Family } \\
\text { size }\end{array}$ & $\begin{array}{l}\text { Labour } \\
\left(\text { man-year }^{1}\right)\end{array}$ & $\begin{array}{l}\text { Deforested } \\
\text { area }(\mathrm{mz})\end{array}$ & $\begin{array}{l}\text { Plot size } \\
(\mathrm{mz})\end{array}$ & Seasons & $\begin{array}{l}\text { Cultivated area } \\
\text { annual basis }(\mathrm{mz})\end{array}$ \\
\hline 8 & 4 & 12 & 8 & 3 & 24 \\
\hline
\end{tabular}

${ }^{1}$ Not including the labour of children below 12 years.

Table 2. Production at representative frontier farm

\begin{tabular}{llllll}
\hline & $\begin{array}{l}\text { Cultivated } \\
\text { area }(m z)\end{array}$ & $\begin{array}{l}\text { Yield } \\
\left(Q^{1} / m z\right)\end{array}$ & $\begin{array}{l}\text { Gross output } \\
(Q Q)\end{array}$ & $\begin{array}{l}\text { Per cent } \\
\text { loss }\end{array}$ & $\begin{array}{l}\text { Net output } \\
(Q Q)\end{array}$ \\
\hline Maize & 12 & 20 & 240 & 30 & 168 \\
Beans & 8 & 10 & 80 & 30 & 56 \\
Rice & 4 & 35 & 140 & 30 & 98 \\
\hline
\end{tabular}

${ }^{1} \mathrm{QQ}=$ quintales.

Sources: Yields: GTZ/MARENA, CIPRES (man-days per mz).

Table 3. Production and imputed income per man-year

\begin{tabular}{llll}
\hline & $\begin{array}{l}\text { Production per } \\
\text { man-year }(Q Q)\end{array}$ & $\begin{array}{l}\text { Output price } \\
(C \$ / Q Q)\end{array}$ & $\begin{array}{l}\text { Imputed frontier income per } \\
\text { average man-year by activity }(C \$)\end{array}$ \\
\hline Maize & 42.0 & 38.7 & $1,625.4$ \\
Beans & 14.0 & 48.9 & 684.6 \\
Rice & 24.5 & 46.8 & $1,146.6$ \\
\hline
\end{tabular}


per man-year at the frontier. The prices are taken from Economic Indicators from the Central Bank (BCN, 1994a) presenting US\$ prices for important agricultural products in Managua.

The fragile forest soil is degrading rapidly due to current management practice. Consequently, after three years a plot is abandoned and new land is cleared. Hence, even a stagnant population at the frontier drives the deforestation process. In addition, high population growth combined with widespread poverty and unemployment in Nicaragua further encourages migration to the frontier where income after all is secure and does not fall below a subsistence level due to the practically unrestricted access to forest land.

According to the stylized description above, the frontier labour force $\left(L_{F}^{t}\right)$ produces $z l_{m z}, z l_{f r}$ and $z l_{a r}$ units of maize, beans, and rice respectively per man-year. The corresponding frontier production level for a single crop $b$ is:

$$
X F_{b}^{t}=z l_{b} L F_{b^{\prime}}^{t} \quad b \in(m z, f r, a r)
$$

where $b$ represents maize $(\mathrm{mz})$, beans (fr), and rice (ar). This production level generates an imputed income $W F^{t}$ per man-year:

$$
W F^{t}=\sum_{b} P F_{b}^{t} z l_{b}^{\prime} \quad b \in(m z, f r, a r)
$$

at the frontier. This is the level of income which is attracting migrators or not, depending on alternative income opportunities in the economy. The product price obtained at the frontier $\left(P F_{b}^{t}\right)$ is set equal to the price $\left(P_{b}^{t}\right)$ facing the market integrated producers of basic grains (maize, beans, and rice) in the economy:

$$
P F_{b}^{t}=P_{b}^{t} \quad b \in(m z, f r, a r)
$$

Production at the frontier is for own consumption and as such, the output of grain has a basic value independent of market prices. However, for accounting purposes it is reasonable to calculate an imputed income based on general market prices. The important assumption for the result is that a change in market prices signals a change in the opportunity cost of remaining within the market economy and not getting access to the frontier diet. If frontier production was commercialized, farm gate prices would in general be lower than in central agricultural areas with better infrastructure and lower transportation cost. By assuming that all output is for auto-consumption we disregard the fact that a minor share of output is commercialized, for instance pigs walking their way to some local marketplace.

Alternative occupation and income is available in the established rural economy, and in urban areas with a probability less than one. Equilibrium is obtained when there is equality between the expected income options. The rural wage level $W R^{t}$, which is an index for wages in established rural production sectors, is equal to the urban wage level $W U_{0}$, adjusted for the probability of being employed in urban sectors:

$$
W R^{t}=\left(1-U R^{t}\right) W U_{0}
$$


$U R^{t}$ is the share of unemployed in the urban economy which is where unemployment exists.

Farming at the frontier is primarily an alternative to rural farming. We assume that landless labourers in rural farming leave for the frontier if income at the frontier is large relative to income in rural farming.

In considering how to model this relationship, an extreme alternative would assume that people leave for the frontier if income at the frontier is larger than income in rural farming, making the income levels equal in equilibrium. A less extreme alternative, which we chose, is to assume a constant elasticity of transformation (CET) macro-relationship between working in rural farming and working at the frontier. This relationship means that some landless labourers leave for the frontier immediately when income at the frontier exceeds income in rural agriculture. Others need a larger income incentive in order to move, for reasons of transport costs, non-pecuniary preferences or risk aversion. In equilibrium, a nonzero income differential is associated with a finite stock of frontier farmers. Among the non-pequniary costs of leaving the established communities in rural areas or the cities is the loss of access to public schools and health services.

To model the CET relationship, we use the dual and specify the macroindex of income in rural agriculture and the frontier:

$$
W X^{t}=\left[\eta_{1}\left(W F^{t}\right)^{\rho}+\eta_{2}\left(W R^{t}\right)^{\rho}\right]^{\frac{1}{\rho}}
$$

$W X$ is the macroindex of income. The elasticity of substitution is -0.6 which suggests significant costs of resettling. We explain the stock of frontier farmers as a function of income relative to the wage index (which, since the wage index consists of frontier income and rural income, is equivalent to defining it as a function of frontier income relative to rural income):

$$
L F^{t}=\eta_{1} L S^{1}\left[W F^{t} / W X^{t}\right]^{\rho-1}
$$

To fully describe the labour market, it remains to determine the stock of landless rural labourers. To do so, the model allocates potential labourers between urban unemployed and rural labour such that the urban unemployed equal the number necessary for the expected urban wage to equal rural income for the landless labourer.

Total labour supply $\left(L S^{\mathrm{t}}\right)$ in the economy grows at an annual rate $g$ :

$$
L S^{t}=L S_{0}(1+g)^{t}
$$

where $L S_{0}$ is the base year labour supply.

Deforestation consists of two elements. One is land cleared by new colonists, and the other is land cleared by the population which has settled at an earlier time, but has to clear new land due to rapid degradation of soil. The deforested area in year $t\left(D F^{t}\right)$ is:

$$
D F^{t}=A\left[L F^{t}-L F^{t-1}+1 / 3 L F^{t-1}\right]
$$

where $A$ is the average cleared area per man-year. We assume that one-third of formerly settled frontier farmers have to clear new land each year. The 
formulation ignores the fact that frontier population is composed of colonial waves with various strength over the years, but this is a minor omission.

\section{Structural adjustment policy and deforestation}

To assess the impact of economic reforms on deforestation we have chosen policy scenarios containing some central stabilization and adjustment elements. These are reducing public expenditures, broadening the tax base, and narrowing the foreign trade gap (devaluation). Below we sketch the background for implementing these policy measures and finally some characteristics of the business as usual scenario. The policy simulations represent a mixture of implemented and planned policies which we simulate over a ten-year period.

\section{Reducing government expenditures}

The Government of Nicaragua faced the challenge to improve fiscal balance in order to ease the inflation pressure in the economy. To reduce the public deficit, total employment in the public sector has been reduced by about 180 thousand employees. Of these, 20 thousand were laid off from the central government's civil staff, while the rest were laid off from defence and public enterprises in roughly equal shares (Government of Nicaragua, 1996). The consequent rise in unemployment can be expected to reduce migration to urban areas by lowering the probability of getting a job and hence the expected income from urban work. The pressure on land might increase. It remains to be seen from model runs to what extent this pressure will affect virgin forests.

2 Increasing government revenues by broadening the tax base while harmonizing tax rates

According to World Bank (1993), around 30 per cent of total tax revenues were still collected from 11 enterprises in an early phase of the reforms. We focus on the impact of broadening the base for a sales tax. Since agricultural sales for pratical purposes still are beyond reach of tax collection, the administrative system must be developed to deal with this. A significant widening of the tax base to include the rural sectors is a medium- or longterm policy-not actually an implemented reform so far. By means of a more efficient administration, public revenues have increased from 16 per cent of GDP in 1990 to 26 per cent in 1995 (Government of Nicaragua, 1996). To illustrate a possible impact of broadening the tax base, we study the case of increasing the effective indirect tax on urban sectors by five percentage points. In rural sectors the tax rates are increased by three percentage points after four years of reforms, assuming that the government has managed to build up the administrative capacity to widen the rural tax base by then. Since government consumption is exogenous in this simulation, the increased revenue is directly transformed to a similar increase in public saving (and total saving).

3 Narrowing the trade balance gap

A macro-devaluation initiated the stabilization efforts in 1991, and was followed by a 20 per cent devaluation in 1993. Thereafter, the government 
carried out a crawling peg exchange rate policy. During devaluations the economy was supported by a strong inflow of foreign aid. Future developments are supposed to rely considerably less on foreign aid, and foreign borrowing options are limited. Hence we study the impact of a reduction in the foreign deficit, which also is to be interpreted as an effect of devaluation.

The impact of these measures (under the assumption of constant real wages) is presented in section 4 . In addition, the cumulative effect of the same policies is studied under a flexible wage regime. The characteristics of the base case or business as usual scenario are given below.

\section{Business as usual}

The 'business as usual' scenario (BAU) portraits the continuation of baseyear behaviour and policies. The labour force is assumed to grow at an annual rate of 3.4 per cent. The population growth was estimated to be 3.2 per cent in the years 1990-1995 and is expected to fall to an average of about 3.0 per cent for the years 1995-2000 (Comision Nacional de Poblacion, 1994). Considering that the population is very young at present, we assume that the working population will grow somewhat faster than the total population in the simulation period.

Tax revenue is mainly generated from a sales tax of 15 per cent. Industries as defined in our model face different rates according to the various exemptions and inefficiencies in tax collection. The rural sectors pay practically no taxes. This is so even for coffee which is an important export crop.

A few adjustments are made to catch some changes likely to occur. The saving rate of campesinos was negative in the base year, owing to credit supply combined with limited enforcement of debt services. A negative saving rate may, however, be a poor estimate of future saving practice because reforms in the financial sector have restricted credit and also seek to re-enforce payment of debt services. This institutional reform is not explicitly dealt with here. However, we have assumed that the campesino saving rate may turn positive because less producer credit is available, and payback ratios are forced upwards. Also, an implicit taxation of agricultural production is phased out by deregulation of agricultural marketing. This may increase rural income and leave more for saving and investment. To account for these possible effects, the campesino saving rate is set to 2.5 per cent after 1991, which is roughly the same level as for workers and urban petty capitalists.

The BAU assumes a constant real urban wage while the level of urban unemployment is variable. The threat of social conflicts and disorder might possibly unite employers and labour unions on approximately such terms.

Public expenditures are assumed to grow at an annual rate of 1.8 per cent. The business as usual scenario is mirroring shrinking investments, increasing unemployment and an annual decline of 3 per cent in GDP. The annually deforested area is increasing by almost 10 per cent per year, making total deforestation in the reserves more than twice the base-year level after 10 years.

The BAU is not a sustainable path, but base year behaviour and restrictions offer a reference point for analysis of various economic reforms, and 
levels of external financing. A main factor behind future sustainability not thoroughly dealt with in this study, is the potential for technological change and increased efficiency following a re-orientation of economic policy. A moderate assumption of a 0.5 per cent technological progress is included in the model runs. Urban-sector efficiency might be expected to improve above this rate, while technological progress in agricultural sectors might be more uncertain, being contingent upon infrastructure and marketing facilities which are not immediately provided by deregulation.

\section{Results from policy simulations}

Below we present the results for each scenario by first pointing at the short-term effects of the implemented policies, and thereafter commenting on the outcome after 10 simulation periods. Table 4 presents the output of model runs by the end of the horizon. Figure 1 presents the effect of single policy measures on GDP, unemployment rate, private consumption and deforestation. Figure 2 displays the development of rural and urban per capita income along with the change in deforestation.

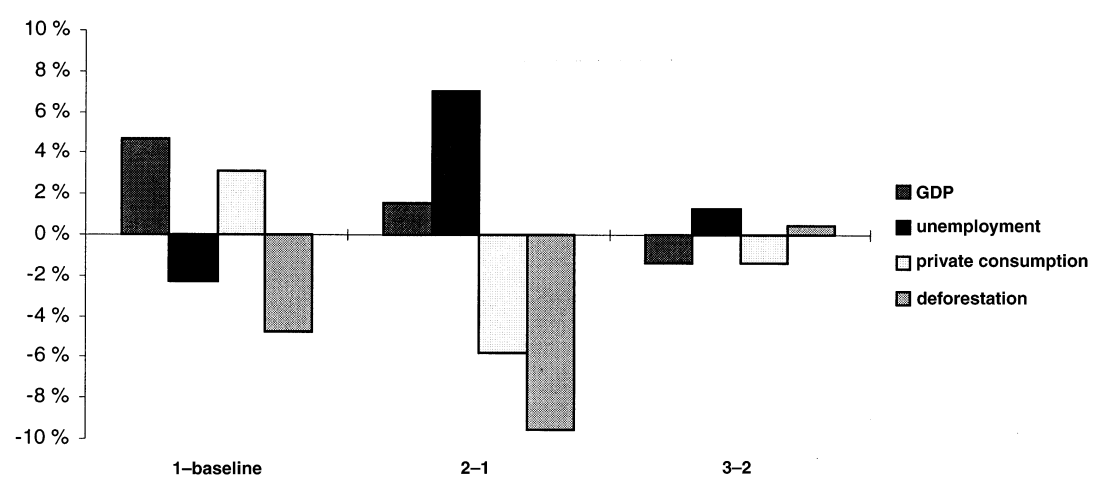

Figure 1

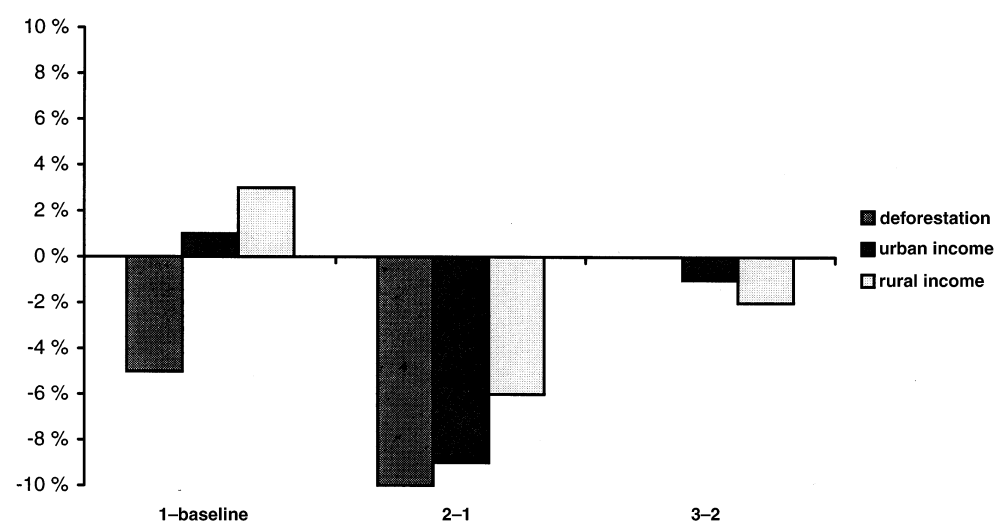

Figure 2 
Table 4. Impact of economic reforms on deforestation and main economic variables in Nicaragua. Deviation from business-as-usual scenario. (Year 2000. Per cent).

\begin{tabular}{lllll}
\hline & $(1)$ & $(2)$ & $(3)$ & $(4)$ \\
& $\begin{array}{l}\text { Reduced } \\
\text { public } \\
\text { expenditures }\end{array}$ & $\begin{array}{l}\text { Sales } \\
\text { tax } \\
\text { reform }\end{array}$ & $\begin{array}{l}\text { Reduced } \\
\text { trade deficit }\end{array}$ & $\begin{array}{l}\text { Flexible real } \\
\text { wages }\end{array}$ \\
& $(1)$ & $(1)+(2)$ & $(1)+(2)+(3)$ & $(1)+(2)+(3)+(4)$ \\
& 4.7 & 6.3 & 4.9 & 47.4 \\
Gross domestic product & 3.1 & -2.8 & -4.2 & 29.5 \\
Private consumption & 4.2 & 3.0 & 2.8 & 50.4 \\
Export & 3.7 & 2.7 & 0.5 & 42.3 \\
Import & - & - & - & -1.0 \\
Urban real wage & 2.5 & -1.0 & -1.6 & 3.3 \\
Rural real wage & 0.5 & -8.9 & -9.9 & 5.0 \\
Per capita rural income & 3.3 & -3.2 & -4.7 & 40.7 \\
Per capita urban income & -2.3 & 4.6 & 6.0 & -78.7 \\
Urban unemployment & -2.3 & -13.9 & -13.5 & -12.2 \\
Annual deforestation & -4.8 & -7.8 & -7.9 & -3.4 \\
Total deforested area & -1.8 & & &
\end{tabular}

\section{Reduced public expenditures}

During the period 1990-1995, fiscal policy has been a key element in the stabilization process. The non-financial public sector balance improved from an 18 per cent deficit in 1990 to a surplus from 1992 on. In this scenario, the annual growth in public expenditures is lowered from 1.8 per cent in the BAU to 1 per cent.

The direct effect of reducing public expenditures is an increase in public savings and the level of investments. Initially-before additional investments have expanded the productive capacity-the impact of improved fiscal balance is a re-allocation of resources towards production of investment goods within the same resource constraints as in the BAU.

Investment demand is directed towards construction and private services, mainly met by domestic supply. The same applies to public demand. What happens when the public sector lowers demand is that additional demand for investment goods is taking over from public expenditures. Consequently, no significant structural changes take place in domestic demand and production, conserving the terms of trade. However, second order price effects tend to favour agricultural sectors. These price effects, together with an increase in urban unemployment of 0.4 per cent make the outcome of frontier farming improve slightly in relative terms, and the annual deforestation increases by 0.3 per cent after 2 years. However, it is an important conclusion that tightening of the budget does not imply mass unemployment and exodus to the agricultural frontier in the short term.

The short-term increase in investment is not taking place at the expense of private consumption, and demand for agricultural products is maintained. The average rural income level is positively affected. Average income for the urban working population (employed or self employed) is also increasing ( 0.4 per cent), reflecting that profit in the informal sector is rising. There is an increase in urban unemployment, though. Still, 
including the unemployed, the average income for the urban population as a whole, is constant. The rural population has a considerably lower income level than the urban population. Consequently, there are some immediate positive distributional elements of this policy, but they are conditional upon increased consumption of natural resource capital, and an increase in urban unemployment. The social impact of increased unemployment is clearly negative, but empirical evidence indicates that family income in the dominant urban region Managua-Masaya is a composite of wage income and profit in self-employed production of goods and services (IHCA, 1986). A broad segment of the urban population might then share benefits as well as disadvantages of this policy, which keeps the average urban income stable in the short term.

The reduction in government spending launches a process of capital accumulation. Over time, increased investment expands the production capacity and income is increasing. By year 2000, GDP is 4.7 per cent above BAU as shown in table 4. Private consumption is also increasing, although slightly less (3.1 per cent).

The investments raise productivity and allow for an overall long-term increase in profits and real rural wages. The higher rural wages attract workers more than being an unemployed urban poor, and the unemployment rate is reduced by 2.3 per cent compared with BAU by the end of the simulation period. The rural per capita income level (consisting of real wage income plus campesino share of profit) increases by 0.5 per cent. The average urban income level increases by as much as 3.3 per cent since the number of unemployed urban workers falls and profit increases for small urban producers.

The frontier farmers do not invest in capital equipment, but compensate declining soil productivity with fresh natural land capital. Hence, productivity is stagnant at frontier farms, which are lagging behind in comparison with the rural wage earners who are the social basis for migration to the frontier. Less people than in the BAU are so poor that remote subsistence farming is their best option. The annual rate of deforestation is reduced by 4.8 per cent compared with BAU. Taking into account that the initial effect of this policy was an increase in migration to the frontier, this indicates a more significant positive long-term effect on deforestation beyond our time horizon. Total deforested area over the simulation period is reduced by 1.8 per cent.

Overall, the policy implies less deforestation. The level of private consumption is conserved in the process of accumulation and growth, which in the early phase of reform is beneficial to the rural population. However, over time the urban population gains more from this policy than the rural. Both unemployed and frontier farmers merge into the stationary agricultural sectors where real wages increase by about 2.5 per cent, but profit in agricultural sectors is not increasing much and rural per capita income is lagging behind the urban income level growth.

Sales tax reform

To mobilize resources for public services and investments, economic reform programmes aim at broadening the tax base. Nicaragua has 
recently increased the government's current income from 16.5 per cent of GDP in 1990 to 26.8 per cent in 1995 (Government of Nicaragua, 1996). In this scenario we study the effect of increasing the sales tax in urban sectors by five percentage points. In the less formal rural sectors, a sales tax of 3 per cent is introduced by year 5 . Scenario 2 in table 4 represents the combined effect of both reduced public expenditures and the sales tax reform by the end of the simulation period.

Initially, only urban sectors face increasing tax rates. The tax increase lowers net producer prices and profits, and the short-term response of urban companies is to lay off workers, since urban real wages are rigid. The increase in investments enhances labour productivity, but in an early phase this effect is small and incapable of compensating fully for the contractive effect of lower urban net producer prices, even though investments are allocated mainly to urban production sectors.

The loss of private income through rising unemployment and the decline in profits makes private consumption fall by 9 per cent after two years. Food is a significant element in consumer demand and prices of food crops fall considerably. Due to the decline in food prices, the terms of trade between basic grains and other consumer goods change markedly. This leaves frontier farmers in a difficult position. In their remote settlements they do not have the option to substitute general consumer goods for basic grains. When food becomes cheaper relative to other consumer goods, it is perceived as increasingly beneficial to get access to and choose from a wider basket of goods and services available to rural and urban labourers with access to markets. Hence, people tend to leave the frontier. This effect dominates over the impact of increasing urban unemployment, which lowers the expected urban wage income and makes people less inclined to stay at the frontier. The annual rate of deforestation falls to 8 per cent below BAU as a short-term effect.

Although the urban sector is the one being levied an additional tax at this stage, the rural sector is carrying the main burden. Real rural wages are reduced by about 5 per cent. Still, the number of rural workers is falling by almost 6 per cent and rural labourers become part of the urban unemployed poor.

In the short term, the urban sales tax generates an economic contraction and aggravates the distributional differences between cities and the countryside. But forest land is preserved even during this crisis due to the increasing relative disadvantage of generating income through basic grain production for subsistence.

Rural sectors are taxed from 1995, contributing to a further increase in public saving and investments. The higher level of investments eventually gives an additional value added. In year 2000, GDP is 1.6 per cent above the previous scenario and 6.3 per cent above BAU. However, this longterm benefit is obtained at a high cost in the sense that the level of private consumption is reduced by almost 6 percentage points compared with the reduced public expenditure scenarios (to a level of 3 per cent below BAU).

The long-term benefits in forest conservation are significant, though. The annual rate of deforestation is reduced by 9 per cent (to 14 per cent below annual deforestation in BAU) after nine years. The migration from the 
countryside to the cities is dampened, but unemployment remains almost 5 per cent above BAU.

The urban population (including the unemployed) has its per capita income reduced by 6 per cent compared with the previous scenario (to 3 per cent below BAU). The elements included in the average per capita urban income are urban wages and profits in the informal sector. For those who are employed or (informally) self employed in the cities, the per capita income level is slightly reduced, because profit in the informal sector is negatively affected. The main change in the urban real income level is due to increased unemployment. The rural sector suffers from the considerable fall in rural real wages.

Except for the beneficial impact on natural resources, there seems to be little to gain from the tax reform within the first decade. But the high investment level which has turned the result from a sharp decline in activity level early on to some positive medium-term results might embed a potential for even higher growth and lower unemployment in the longer term, in particular if the technological improvements associated with the higher investment rates are taken into account. However, if a significant contribution to economic growth and increased welfare will come after 15 years or so, the younger half of the population at that time would have been waiting all their childhood for improvements in nutrition, health and education so crucial and conditional for long-term development. The longterm structural impact of the tax reform might still be beneficial, but the tax reform as a means of stabilization should be complemented by measures which increase productivity and compensate the rural population where the incidence of poverty is high.

The investments are increased by roughly the same magnitude in this tax reform scenario as in the previous scenario. In the case of reducing public expenditure, growth is stimulated from the outset and over the whole decade, raising GDP 4.7 per cent above BAU in year 2000. Financing the same amount of investments by indirect taxes only adds 1.6 per cent to GDP within our time horizon. Why does it make such a difference whether investments are financed by cutting expenditures or raising the tax rate? The reason for sluggish performance under the tax reform is that raising the urban sales tax eats up the initial growth impulse created by the investments generated by the tax revenue. Urban sectors dominate the investment activity, so the potential to enhance growth through investments in the current regime lies within the urban economy. When urban sales taxes are increased, the investment-induced increase in labour productivity and profits is withdrawn. Actually, the urban economy is contracting, and through lay offs and lower levels of income and consumption this strongly affects the rural income level. Over time, increased growth is showing up, but the rural income is lagging behind the urban income growth. Rural growth and welfare depend upon the level of private consumption and the associated demand for food crops, since (credit and) investments do not reach far out in the fields. More direct gains from increased productivity through investments are not easily available to the countryside.

When cutting public expenditures, the effect of this self-defeating mech- 
anism involving urban investments and urban taxes does not show up. Additional investments are allowed to generate increased urban income which keeps up demand for food and generates rural income as well. Also, the composition of domestic demand is hardly disturbed when increased investment demand is substituted for public demand. The sectoral structure remains stable, ensuring that no income loss occurs due to structural changes, since sectors differ somewhat with respect to profitability.

\section{Reducing foreign transfers}

Stabilization and structural reforms are implemented to stimulate growth and investments and thus reduce dependency on foreign development assistance. In this scenario we trace the impact of reducing the external deficit by US\$ 50 millions per year from 1995, a 15 per cent annual reduction compared to the BAU deficit level. The policy is implemented late in the simulation period, so the time horizon is short anyway. The results cover short- or medium-term effects (five simulation periods) only.

The first-order effect of the reduction in foreign savings is to lower total investments by an equal amount. However, although economic growth is hampered to the extent that nearly all GDP gains from the sales tax are neutralized, the investment level is not reduced proportionally due to relative price effects.

When the inflow of foreign currency is reduced, the stricter trade balance forces the real exchange rate upwards, protecting exports, while imports nearly fall to BAU level, in spite of an activity level 5 per cent above the reference scenario. The domestic price level is falling, and investment demand, which mainly consists of domestic goods and services, is encouraged by the relative change between domestic and world market price levels.

The decline in activity level increases the level of urban unemployment. The increase in the unemployment rate lowers the expected wage income in the cities, and the equilibrium rural wage is reduced more than the urban nominal wage level. The rural population is getting poorer. Per capita real income is reduced by 1 per cent to 10 per cent below BAU. Behind this change lies a reduction in real rural wages ( 0.5 per cent) and a decline in rural profits ( 2 per cent). Fewer opportunities for earning rural wage income will generally encourage migration to the frontier and to the cities. However, urban demand for labour is hardly increasing and the migrators are adding to the number of unemployed. The urban average income is reduced by 1.5 per cent at the end of the simulation period.

Average incomes for both the urban and rural population are reduced. Still, deforestation is only slightly increased. The migration flow is held back because food items (basic grains) are becoming relatively cheaper in the markets, which partly compensates for the effect of the fall in income levels. Hence, the income level and not deforestation is of concern when the external deficit is being reduced.

\section{Flexible real wages}

So far, the policies introduced in the scenarios have moved GDP in year 2000 a few per cent above BAU. Such gains are significant if combined with 
beneficial distributional effects and less pressure on natural capital, but do not qualify as a take off in a development context. A common feature of these scenarios is that they hinge upon the assumption that rigidities in the labour market are sustained during the simulation period of ten years. If market forces replace union control of the urban labour market, and real wages in urban sectors start to respond to the level of unemployment, the outcome might turn out differently. In the scenario presented here, it is assumed that the real urban wage is flexible, and that the market is successful in stabilizing the unemployment at 9 per cent, assumed to be a structurally determined minimum level. All policies introduced in earlier scenarios are retained.

By removing the assumption of rigid urban real wages, the profitability is increasing and GDP jumps to a level of 9 per cent above BAU after year 2 of the simulation period.

The production costs level is falling 2.3 per cent, owing to the urban real wage decline of about 1 per cent. The agricultural sectors benefit from increased food demand and a substantial rise in output prices, which drives up real rural wages by 5 per cent.

With such immediate improvements in rural workers' income level, one might expect the subsistence production at the agricultural frontier to dwindle. However, the prices of basic grains are increasing significantly, reducing the value of access to the broader consumer goods basket in comparison to frontier basic grain production. Within the market economy and for a certain real wage, less goods and services are now available in addition to basic food consumption, which has become significantly more costly. Even though employed work in the countryside is being rewarded higher than before, and expected urban real wage is increasing, this price effect is strong enough to encourage the migration to the frontier. Hence, in the short run, the rate of deforestation is actually increasing.

The deflationary effect associated with less rigid urban real wages encourages exports, in particular exports from urban sectors. The increase in profits stimulates investments, since saving rates are higher among capitalists than workers.

Unemployment is reduced by assumption and the average income for the urban citizen increases by 4.5 per cent in the short term. It actually turns out that urban real wage is reduced by less than 1 per cent. Rural per capita income is increasing by 5 per cent. The beneficiaries of the flexible real wage in the short term are thus the former unemployed and people in the countryside, who regain their income level from BAU after the unfavourable impact of the previous policies.

The consumption level is kept relatively low and real investments high due to the considerable increase in profits. In the longer term this initiates a take off in terms of economic growth, with GDP almost 50 per cent above BAU after a decade.

The flexible urban wage initiates rapid growth through an (essentially urban) profit-driven accumulation and growth process. Employment is increasing, and urban real wages are only moderately lowered by 1 per cent by the end of the simulation period. High investments cause a significant positive shift in labour productivity, which contributes to keep up the 
urban wage level. Consumer demand is increasing (although less than GDP) and the price of basic food items goes up as well. Basic grain prices rise considerably relative to other goods and services in the consumer basket available outside the remote frontier and inside the market economy. The intense urban investment activity ensures that a wide variety of consumer goods are supplied at moderate prices due to the continuous rise in urban productivity. But still it is so that the price effect through increasingly expensive food in the markets dominates over the incentives to leave the frontier related to the positive income shift in stationary agriculture and in the cities. Consequently colonists stick to subsistence farming at the frontier, limiting the reserve of labour available for the growth sectors, which also helps to keep up the general wage level.

In spite of the significant increase in economic growth, the impact on deforestation is still negative after ten years. In this case, there is a clear contradiction between urban economic growth and the conservation of natural resources.

Whether real wages are flexible or not strongly affects the distribution between profit and wage income. Flexible wages raise profits which in turn are invested and generate growth particularly in the urban sectors. This stimulation of the urban economy is not capable of counter-weighing the negative impact on rural income opportunities, since private consumption and demand for food is rising more slowly than GDP. Consequently, the contribution from flexible wages is to increase deforestation.

\section{Conclusion}

In this paper we have studied the impact of various economic policies on economic growth and deforestation in Nicaragua by means of a computable general equilibrium model. A key feature of this model is that the income level at the agricultural frontier is determined by the price of basic grains, and not directly linked to the alternative cost of labour within the market economy. This means that deforestation by squatters is particularly sensitive to distributional aspects which affect the level of private consumption, the demand for food and food prices.

It is shown that some policies initially intensify the clearing of forest land, but turn out to ease the pressure on forest capital over time. This trade-off between short- and long-term effects should be taken into account under policy formation. An argument for accepting a short-term increase in deforestation could be positive distributional effects, as experienced in the case of reduced public expenditures.

Noticeably, improving the fiscal balance by cutting public expenditures or by means of a sales tax reform both enhance economic growth and conservation of forests. The former policy is efficient in stimulating growth, while the latter is efficient in conservation. While the rural income level is conserved under reduced public expenditures, it is being eroded by the sales tax increase, through a demand-induced decline in prices of basic grains. With low prices on basic grain, the migration to urban surroundings is seen as more beneficial because cheaper grain makes it less hard to make financial room for a subsistence food consumption level in the cities with a given real wage; i.e. the alternative cost of staying at the frontier is 
rising. Thus, the forest conservation associated with a rising sales tax is driven by a general rural poverty increase.

A flexible urban wage setting would generate more rapid deforestation. The economy would grow at a considerably higher rate, but the rural wage level would not be much higher than in the reference scenario. A significant increase in food prices would cancel out the potential benefit from improved and less uncertain income opportunities within the market economy. Subsistence farming would be increasingly attractive under the new price regime. A conclusion is that rapid growth does not guarantee more forest conservation, as illustrated under the flexible urban wage regime.

Monitoring and enforcement problems of remote forests in Nicaragua may exclude market based measures against deforestation by squatters, and also a Pigouvian approach may seem inappropriate as a corrective measure among the poorest groups of the population. Our study has shown that the general equilibrium effects of economic policies on the deforestation rate are considerable, and may be used to identify indirect measures to control deforestation.

\section{References}

Alfsen, K.H., M.A. De Franco, S. Glomsrød and T. Johnsen (1996), 'The cost of soil erosion in Nicaragua', Ecological Economics 16(1): 29-145.

Alfsen K.H., T. Bye, S. Glomsrød, and H. Wiig (1995), 'Integrated assessment of soil degradation and economic growth in Ghana', Documents 95/8, Statistics Norway.

Aune, J., S. Glomsrød, V. Iversen, and H. Wiig (1996), 'Structural adjustment and land degradation: a CGE analysis for Tanzania', Paper prepared for seminar on structural adjustment policies and the environment, Agricultural University of Norway.

(BCN) Banco Central de Nicaragua (1994), 'Letter of intent' to IMF/General Director. Managua, April 16, 1994.

(BCN) Banco Central de Nicaragua (1994a), Indicadores de Actividad Economica a Agosto 1994, Managua.

Comision Nacional de Poblacion (1994), 'Poblacion y Desarollo, Ministerio de Accion Social', Documento 02/02/14/07/94, Managua.

CIPRES (Centro para la Investigacion, la Promocion y el Desarollo Rural y Social) (1992), 'El campesinado en la zona de amortiguamiento de la reserva biologica', Cuadernos CIPRES/13.

Deacon, R.T. (1995), 'Assessing the relationship between government policy and deforestation', Journal of Environmental Economics and Management 28: 1-18.

De Franco, M.A., S. Glomsrød, H. Høie, T. Johnsen, and E. Marin Castillo (1993), 'Soil erosion and economic growth in Nicaragua', Notater 93/22, Statistics Norway.

Dervis, K., J. de Melo, and S. Robinson (1982), General Equilibrium Models for Development Policy, Cambridge: Cambridge University Press.

Gibson, B. (1993), 'Nicaragua', in L. Taylor, ed., The Rocky Road to Reform, Cambridge, MA.

Government of Nicaragua (1996), Document prepared for the Consultative Group Meeting, Washington DC, June 17-18.

GTZ/MARENA (1992), Estudio Básico. Protectión de Recursos naturales y Desarollo Rural sustenido en la Zona Río Waspute-Bonanza-Siuna Región Autónoma Atlántico Norte (RAAN) de Nicaragua, Managua. 
Harris, J. and M.P. Todaro (1970), 'Migration, unemployment and development: a two sector analysis', American Economic Review 60(1): 126-142.

IHCA (Instituto Histórico Centroamericano) (1986), 'Managua's economic crisishow do the poor survive?' Envío 5(66): 36-56, Managua.

Lutz, E. and H. Daly (1990), 'Incentives, regulations and sustainable land use in Costa Rica', Environment Working Paper 61, The World Bank, Washington DC.

Monge, M.D. (1995), 'Deforestacion del bosque tropical humedo y frontera agricola en Nicaragua: Una Caracterizacion', Working Paper, Instituto Centroamericano de Administracíon de Empresas (INCAE), Managua.

Persson, A.B. and M. Munasinghe (1995), 'Natural resource management and economywide politics in Costa Rica: A computable general equilibrium (CGE) modelling approach', The World Bank Economic Review, 9(2): 259-285.

Thiele, R. and M. Wiebelt (1993), 'National and international policies for tropical rain forest conservation-a quantitative analysis for Cameroon', Environmental and Resource Economics 3: 501-531.

World Bank (1993), 'Nicaragua, Stabilization and adjustment: enabling private sector-led growth', Work document, Consultative Group Meeting for Nicaragua, 2 April 1993. Country Dept. II, Latin America and the Caribbean.

\section{Appendix}

\section{An Applied General Equilibrium (AGE) model for Nicaragua}

\section{Model equations}

1 Composite price: $P C_{i} \cdot X C_{i}=P D_{i} \cdot X D_{i}+p m_{i} \cdot M_{i} \quad i \in I-I M$

2 Composite price in non-importing sectors:

$$
P C_{i}=P D_{i}
$$

$i \in I-I M$

3 Value of sale (gross revenue):

$$
P_{i} \cdot X i=P D_{i} \cdot X D_{i}+p e_{i} \cdot E_{i} \quad i \in E X
$$

4 Unit value of sale in non-exporting sectors:

$$
P_{i}=P D_{i} \quad i \in I-E X
$$

5 Price on capital: $\quad P K_{i}=\sum_{j} P C_{j} \cdot$ imat $_{j i} \quad i, j \in I$

6 Activity level, exporting sectors CET (note: $\rho_{\mathrm{ei}} \geq+1$ ):

$$
X_{i}=a t_{i} \cdot\left[\gamma_{i} \cdot E_{i}^{\rho_{e i}}+\left(1-\gamma_{i}\right) \cdot X D_{i}^{\rho_{e i}}\right]^{\frac{1}{\rho_{e i}}} \quad i \in E X
$$

7 Activity level, non-exporting sectors:

$$
X_{i}=X D_{i}
$$

8 Commodity composition of output:

$$
\frac{E_{i}}{X D_{i}}=\left\langle\frac{p e_{i}}{P D_{i}} \cdot \frac{1-\gamma_{i}}{\gamma_{i}}\right\rangle \frac{1}{\rho_{e i}-1} \quad \quad i \in E X
$$

9 Composite commodities CES:

$$
X C_{i}=a c_{i} \cdot\left[\delta_{i} \cdot M_{i}^{-\rho_{m i}}+\left(1-\delta_{i}\right) \cdot X D_{i}^{-\rho_{m i}}\right]^{\frac{-1}{\rho_{m i}}} \quad i \in I M
$$


10 Output in non-importing sextors:

$$
X C_{i}=X D_{i}
$$

11 Demand for imports:

$$
\frac{M_{i}}{X D_{i}}=\left\langle\frac{P D_{i}}{p m_{i}} \cdot \frac{\delta_{i}}{1-\delta_{i}}\right\rangle^{\frac{1}{1+\rho_{m i}}} \quad i \in I M
$$

12 Unit cost: $\quad \operatorname{COST}_{i}=\sum_{j} P C_{j} \cdot a_{j i}+W_{i} \cdot L C_{i} \quad i, j \in I$

13 Profit:

$$
\operatorname{GAN}_{i}=\left[P_{i} \cdot\left(1-t v_{i}\right)-\operatorname{COST}_{i}\right] \cdot X_{i} \quad i \in I
$$

Income and consumption

14 Income working class:

$$
Y_{w k}=\sum_{i} W_{i} \cdot L C_{i} \cdot X_{i}+e r \cdot t r x k_{w k} \quad i \in I
$$

15 Income camposino class:

$$
Y_{c p}=\sum_{i} d g c_{i} \cdot G A N_{i} \quad i \in R
$$

16 Income producers class:

$$
Y_{p r}=\sum_{i} d g s_{i} \cdot G A N_{i}+e r \cdot \operatorname{trxk}_{p r} \quad i \in U
$$

17 Income capitalist class:

$$
\begin{array}{cll}
Y_{k p}=\sum_{i}\left(1-d g c_{i}\right) \cdot G A N_{i}+\sum_{j}\left(1-d g s_{j}\right) \cdot G A N_{j}+e r \cdot t r x k_{k p} & i \in R, j \in U \\
18 \text { Expenditure: } & \operatorname{EXPEND}_{k}=\left(1-s_{k}\right) \cdot\left(1-t d_{k}\right) \cdot Y_{k} & k \in K
\end{array}
$$

19 Basic consumption:

$$
\operatorname{SUB}_{k}=\sum_{i} \mathrm{csub}_{i k} \cdot P C_{i} \quad i \in I, k \in K
$$

20 Private consumption (LES):

$$
P C_{i} \cdot C D_{i k}=P C_{i} \cdot c_{s u b}+q_{i k} \cdot\left(E_{X P E N D}-S U B_{k}\right) \quad i \in I, k \in K
$$

Wage formation

21 Rural sector wage:

$$
W_{i}=\text { relw }_{i} W R \quad i \in R
$$

22 Urban sector wage:

$$
W_{i}=r e l w w_{i} W_{i 0} I P C_{w k, t-1} \quad i \in R
$$

Labour market

23 Labour supply: $\quad L S=l s_{0}(1+g)^{t}$

24 Frontier labour: $\quad L F=\frac{\eta_{1}}{W F_{0}} L S\left(\frac{W F}{W X}\right)^{\rho-1}$

25 Rural wage index:

$$
W X=\left(\eta_{1} W F^{\rho}+\eta_{2} W R^{\rho}\right)^{\frac{1}{\rho}}
$$

26 Frontier labour: $\quad L F=(1-U) L S-\sum_{\mathrm{i}} L C_{\mathrm{i}} X_{\mathrm{i}} \quad i \in I$ 
27 Unemployment: $\quad W R=w u_{0}(1-U) I P C_{w w k, t-1} \frac{1-u_{r 0}}{1-u_{0}}$

Frontier production and income

28 Frontier prices: $\quad P F_{i}=P_{i} \quad i \in B$

29 Production function:

$$
X F_{i}=z l_{i} L F \quad i \in B
$$

30 Income per man-year:

$$
W F=\sum_{i} P F_{i} z l_{i} \quad i \in B
$$

31 Frontier income: $Y_{f a}=W F \cdot L F$

Investment and saving

32 Capital in period $t+1$ :

$$
K F_{i, t+1}=K F_{i, t} \cdot(1-\text { depre })+D K_{i t} \quad i \in I
$$

33 Total investments equal savings:

$$
I N V=\sum_{k} s_{k} \cdot\left(1-t d_{k}\right) \cdot Y_{k}+S G O B+e r \cdot s f o r \quad k \in K
$$

34 Investment by destination:

$$
I N V=\sum_{i} P K_{i} \cdot D K_{i} \quad i \in \mathrm{I}
$$

35 Sectoral investment:

$$
D K_{i}=\text { kshare }_{i} \cdot \text { DKTOT } \quad i \in I
$$

Government

36 Government revenue:

$G R=\sum_{i}\left[t v_{i} \cdot P_{i} \cdot X_{i}+\frac{t m_{i}}{1+t m_{i}} \cdot p m_{i} \cdot M_{i}+t e_{i} \cdot p e_{i} \cdot E_{i}\right]+\sum_{k} t d_{k} \cdot Y_{k} \quad i \in I, k \in K$

37 Government expenditure:

$$
G D_{i}=\text { gshare }_{i} \cdot \text { gdtot }_{0} \quad i \in I
$$

38 Government consumption:

$$
G R=\sum_{i} P C_{i} \cdot G D_{i}+S G O B \quad i \in I
$$

Equilibrium of demand and supply

$39 \mathrm{XC}_{i}=\sum_{j} a_{i j} \cdot X_{j}+\sum_{k} C D_{i k}+G D_{i}+\sum_{j} i m a t_{i j} \cdot D K_{j}+\operatorname{csub}_{i, f a} \quad i \in I, k \in K$

Production

40 Production: $\quad X_{i}=a d_{i} \cdot b_{i} \cdot\left[L C_{i} \cdot X_{i}\right]^{a} \cdot K F_{j}{ }^{1-a_{i}} \quad i \in I$

41 Consumer price index:

$$
I P C_{k}=\frac{\sum_{i} P C_{i} \cdot C D_{i k}}{\sum_{i} C D_{i k}}
$$

42 Demand for labour:

$$
W_{i} \cdot L C_{i}=\frac{\alpha_{i}}{1-\alpha_{i}} \cdot \frac{G A N_{i}}{X_{i}}
$$




\section{List of variables}

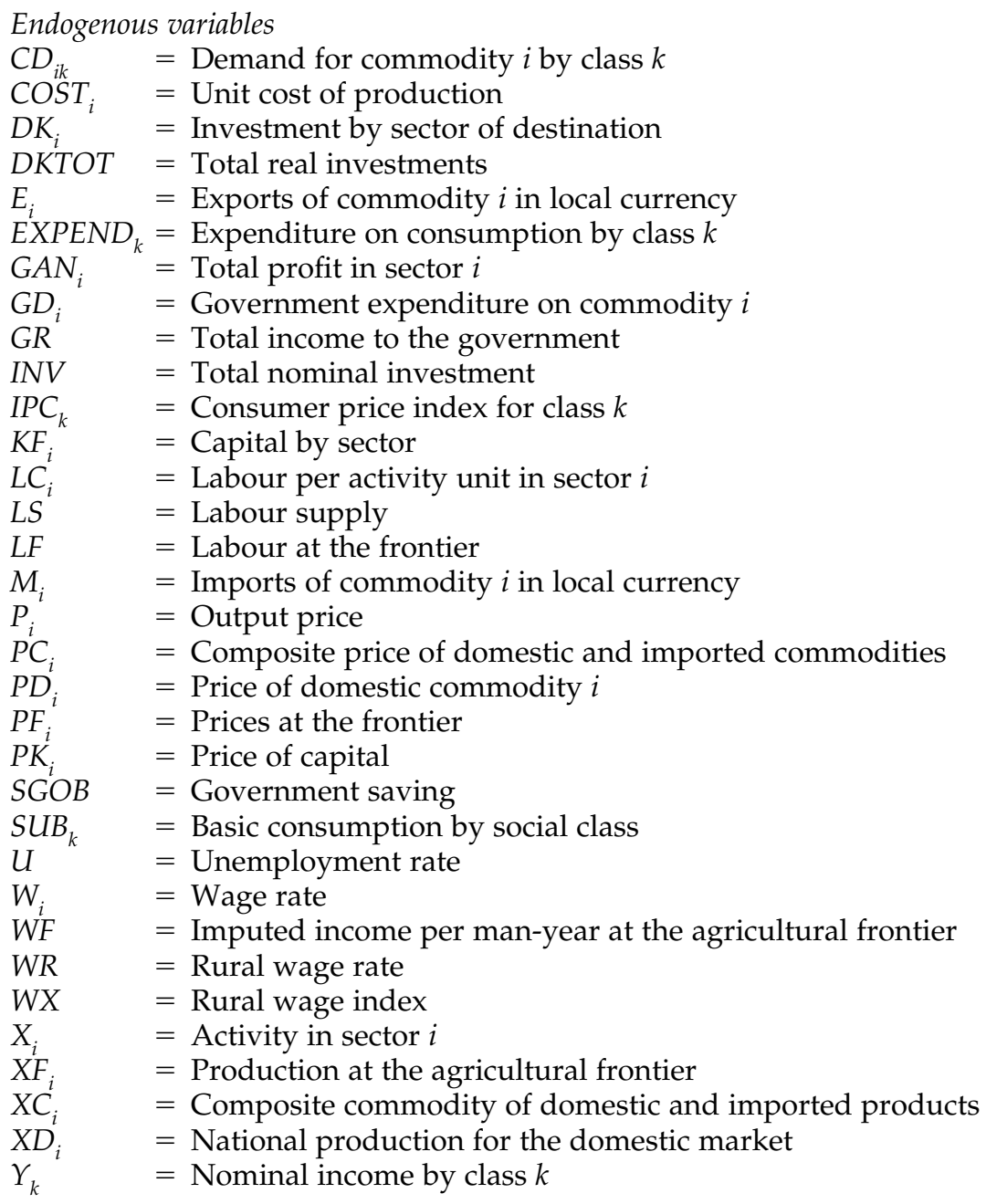

\section{Exogenous variables and parameters}

$\begin{array}{ll}\alpha_{i} & =\text { Cost share of labour } \\ \gamma_{i} & =\text { Share parameter in export equation } \\ \delta_{i} & =\text { Share parameter in creation of composite commodity } \\ \eta_{1} & =\text { Allocation parameter } \\ \eta_{2} & =\text { Allocation parameter } \\ \rho & =\text { Transformation parameter in rural wage index } \\ \rho_{e i} & =\text { Transformation parameter in export equation } \\ \rho_{m i} & =\text { Transformation parameter in import equation } \\ a_{i j} & =\text { Input-output coefficient } \\ a c_{i} & =\text { Shift parameter in creation of composite commodity } \\ a d_{i} & =\text { Shift parameter in Cobb-Douglas production function }\end{array}$




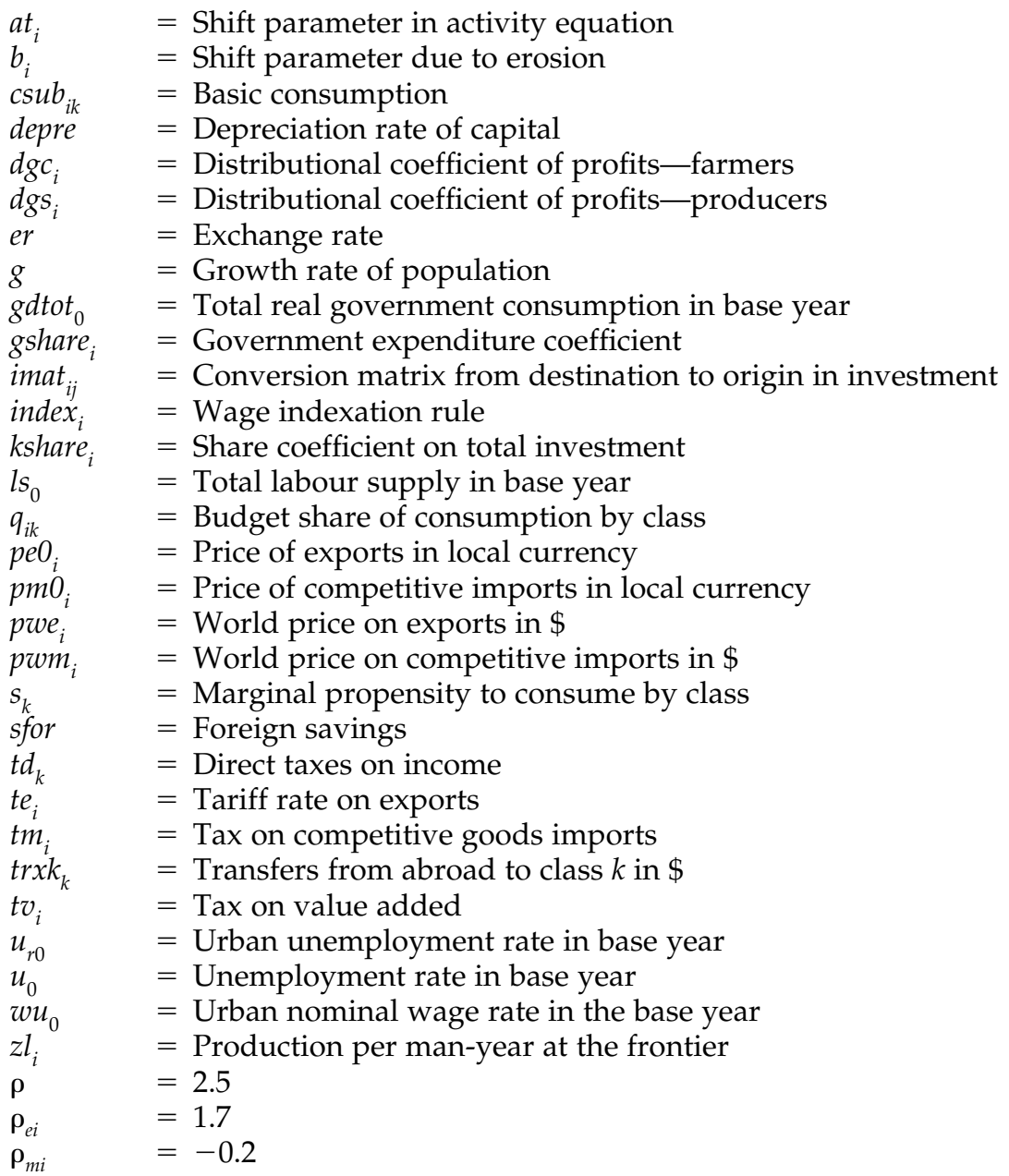


List of sectors (I)

\begin{tabular}{|c|c|c|c|c|c|c|c|}
\hline No. & $\begin{array}{l}\text { Abbrevi- } \\
\text { ation }\end{array}$ & Name & $\begin{array}{l}\text { Agr. } \\
\text { frontier }\end{array}$ & $\begin{array}{l}\text { Agri- } \\
\text { culture }\end{array}$ & $\begin{array}{l}\text { Rural/ } \\
\text { Urban }\end{array}$ & Import & Export \\
\hline 1 & $\mathrm{CF}$ & Production of Coffee & & AGR & $\mathrm{R}$ & & EX \\
\hline 2 & AG & Production of Cotton & & AGR & $\mathrm{R}$ & & EX \\
\hline 3 & BA & Production of Bananas & & AGR & $\mathrm{R}$ & & EX \\
\hline 4 & AJ & Production of Sesame & & AGR & $\mathrm{R}$ & IM & EX \\
\hline 5 & $\mathrm{AZ}$ & Production of Sugar & & AGR & $\mathrm{R}$ & & \\
\hline 6 & MZ & Production of Maize & B & AGR & $\mathrm{R}$ & IM & \\
\hline 7 & FR & Production of Beans & B & AGR & $\mathrm{R}$ & IM & \\
\hline 8 & $\mathrm{AR}$ & Production of Rice & B & AGR & $\mathrm{R}$ & $\mathrm{IM}$ & \\
\hline 9 & SG & Production of Sorghum & & AGR & $\mathrm{R}$ & $\mathrm{IM}$ & \\
\hline 10 & OA & Other agriculture & & AGR & $\mathrm{R}$ & IM & EX \\
\hline 11 & PC & Production of Cattle & & AGR & $\mathrm{R}$ & IM & \\
\hline 12 & SV & Forestry & & & $\mathrm{R}$ & IM & EX \\
\hline 13 & PS & Fishery & & & $\mathrm{R}$ & & EX \\
\hline 14 & MN & Mining & & & $\mathrm{R}$ & IM & EX \\
\hline 15 & $\mathrm{AL}$ & $\begin{array}{l}\text { Production of Food } \\
\text { and Beverages }\end{array}$ & & & $\mathrm{U}$ & IM & EX \\
\hline 16 & VT & Production of Textiles & & & U & IM & EX \\
\hline 17 & QM & Production of Chemicals & & & $\mathrm{U}$ & IM & EX \\
\hline 18 & PT & Oil production & & & $\mathrm{U}$ & IM & EX \\
\hline 19 & OV & Other industries & & & $\mathrm{U}$ & $\mathrm{IM}$ & EX \\
\hline 20 & EL & Production of Electricity & & & U & IM & EX \\
\hline 21 & $\mathrm{AP}$ & Water services & & & U & & \\
\hline 22 & CT & Construction & & & U & & \\
\hline 23 & $\mathrm{SC}$ & Other Services & & & U & IM & EX \\
\hline 24 & TR & $\begin{array}{l}\text { Production of Transport } \\
\text { and Communication } \\
\text { Services }\end{array}$ & & & $\mathrm{U}$ & $\mathrm{IM}$ & EX \\
\hline 25 & ES & Education and health & & & U & & \\
\hline 26 & $\mathrm{CM}$ & Trade & & & U & & \\
\hline
\end{tabular}

Social classes $(K)$

\begin{tabular}{lll}
\hline 1 & CP & Campesinos (farmers) \\
2 & WK & Urban workers \\
3 & PR & Urban small proprietors (small producers) \\
4 & KP & Capitalists \\
5 & FA & Frontier farmers \\
\hline
\end{tabular}


